Supporting Information

\title{
Design Superior Alkaline Hydrogen Evolution Electrocatalyst by Engineering Dual Active Sites for Water Dissociation and Hydrogen Desorption
}

Jianpo Chen, ${ }^{1}$ Qiuyan Jin, ${ }^{1}$ Yinwei $\mathrm{Li},{ }^{2}$ Yan Li, ${ }^{1 *}$ Hao Cui ${ }^{1 *}$ and Chengxin Wang ${ }^{1 *}$

${ }^{1}$ State Key Laboratory of Optoelectronic Materials and Technologies, School of Materials Science and Engineering, The Key Laboratory of Low-Carbon Chemistry \& Energy Conservation of Guangdong Province, Sun Yat-sen University, Guangzhou 510275, China.

${ }^{2}$ School of Physics and Electronic Engineering, Jiangsu Normal University, Xuzhou 221116, People's Republic of China

*Corresponding author: Fax: +86-20-8411-3901; E-mail: liyan266@mail.sysu.edu.cn; cuihao3@mail.sysu.edu.cn; wchengx@mail.sysu.edu.cn; 
Table of contents:

\section{Part 1 Experimental Supplement}

Figure S1. The XRD pattern (a) and SEM image (b) of nickel foam.

Figure S2. XRD patterns of precursors with different feeding ratios of Co and W.

Figure S3. XRD patterns of $\mathrm{Co}-\mathrm{WO}_{2} / \mathrm{Co}_{\mathrm{x}} \mathrm{W} / \mathrm{NF}$ with different feeding ratios of Co and $\mathrm{W}$.

Figure S4. The XRD pattern of the catalyst annealed at $700{ }^{\circ} \mathrm{C}$ in $\mathrm{H}_{2}$-Ar gas mixture for 2 hours.

Figure S5. SEM images of precursor (Co-W-1/3-1).

Figure S6. Low magnification SEM image of $\mathrm{Co}-\mathrm{WO}_{2} / \mathrm{Co}_{\mathrm{x}} \mathrm{W} / \mathrm{NF}-1 / 3$.

Figure S7. SEM image and corresponding Energy dispersive X-ray elemental mapping images of $\mathrm{Co}-\mathrm{WO}_{2} / \mathrm{Co}_{\mathrm{x}} \mathrm{W} / \mathrm{NF}-1 / 3$.

Figure S8. Low magnification TEM image of $\mathrm{Co}-\mathrm{WO}_{2} / \mathrm{Co}_{\mathrm{x}} \mathrm{W} / \mathrm{NF}-1 / 3$.

Figure S9. High magnification TEM images of Co- $\mathrm{WO}_{2} / \mathrm{Co}_{\mathrm{x}} \mathrm{W} / \mathrm{NF}-1 / 3$.

Figure S10. Co $2 p$ XPS spectra and Co/W mole ratio of the samples.

Figure S11. XPS spectrum of O 1 s of $\mathrm{WO}_{2} / \mathrm{NF}$ (a) and Co- $\mathrm{WO}_{2} / \mathrm{Co}_{\mathrm{x}} \mathrm{W} / \mathrm{NF}-1 / 3$ (b).

Figure S12. The polarization curve tested by step change method and the linear sweep voltammetry curve with a scan rate of $0.5 \mathrm{mV} \mathrm{s}{ }^{-1}$ of $\mathrm{Co}-\mathrm{WO}_{2} / \mathrm{Co}_{\mathrm{x}} \mathrm{W} / \mathrm{NF}-1 / 3$.

Figure S13. Polarization curves of $\mathrm{Co}-\mathrm{WO}_{2} / \mathrm{Co}_{\mathrm{x}} \mathrm{W} / \mathrm{NF}$ with different feeding ratio of Co and $\mathrm{W}$.

Figure S14. The Polarization curves (a) and Tafel slopes (b) of Co-W/NF-Air, Co-W/NF-Ar and Co-WO2/Co $\mathrm{W} / \mathrm{NF}-1 / 3$, respectively.

Figure S15. The Polarization curves (a) and Tafel slopes (b) of Co-W/NF-Air, $\mathrm{Co}-\mathrm{W} / \mathrm{NF}-\mathrm{Ar}$ and $\mathrm{Co}-\mathrm{WO} 2 / \mathrm{Co}_{\mathrm{x}} \mathrm{W} / \mathrm{NF}-1 / 3$, respectively.

Figure 16. The LSV curves with (solid line) and without (short dot line) iR-compensated of the samples.

Figure S17. Nyquist plots of $\mathrm{Co}-\mathrm{WO}_{2} / \mathrm{Co}_{\mathrm{x}} \mathrm{W} / \mathrm{NF}-1 / 3$ at different overpotential. Inset: the equivalent circuit diagram. 
Figure S18. Cyclic voltammograms at different scan rates of a) $\mathrm{Co}-\mathrm{WO}_{2} / \mathrm{Co}_{\mathrm{x}} \mathrm{W} / \mathrm{NF}-1 / 3$ and b) $\mathrm{WO}_{2} / \mathrm{NF}$. c) Double-layer capacitance $\left(\mathrm{C}_{\mathrm{dl}}\right)$ of $\mathrm{Co}-\mathrm{WO}_{2} / \mathrm{Co}_{\mathrm{x}} \mathrm{W} / \mathrm{NF}-1 / 3$ and $\mathrm{WO}_{2} / \mathrm{NF}$.

Figure S19. XRD patterns of $\mathrm{Co}-\mathrm{WO}_{2} / \mathrm{Co}_{\mathrm{x}} \mathrm{W} / \mathrm{NF}-1 / 3$ before and after chronoamperometry experiment.

Figure S20. SEM images of $\mathrm{Co}-\mathrm{WO}_{2} / \mathrm{Co}_{\mathrm{x}} \mathrm{W} / \mathrm{NF}-1 / 3$ after chronoamperometry experiment.

Figure S21. TEM image and SAED of the amorphous region of $\mathrm{Co}-\mathrm{WO}_{2} / \mathrm{Co}_{\mathrm{x}} \mathrm{W} / \mathrm{NF}-1 / 3$ after chronoamperometry experiment.

Table S1. Comparisons of HER performance of $\mathrm{Co}-\mathrm{WO}_{2} / \mathrm{Co}_{\mathrm{x}} \mathrm{W} / \mathrm{NF}$ with other reported non-noble-metal catalysts.

\section{Part 2 Calculational Supplement}

Figure S22. The top views and side views of the as-built models of $\mathrm{WO}_{2}(011)$, $\mathrm{Co}-\mathrm{WO}_{2}(011)$ and amorphous $\mathrm{Co}_{\mathrm{x}} \mathrm{W}$ slab.

Table S2. Surface energies $\left(\mathrm{J} / \mathrm{m}^{2}\right)$ of different surfaces of $\mathrm{WO}_{2}$

Table S3. The adsorption free energies $(\mathrm{eV})$ of $\mathrm{H}_{2} \mathrm{O}$ and $\mathrm{H}$ on $\mathrm{WO}_{2}(011), \mathrm{Co}-\mathrm{WO}_{2}$ (011) and $\mathrm{Co}_{\mathrm{x}} \mathrm{W}$, respectively.

Table S4. Free energy barriers (eV) of Volmer, Tafel, and Heyrovsky steps.

Figure S23. The top view and the side view of the Tafel step on $\mathrm{Co}-\mathrm{WO}_{2} / \mathrm{Co}_{\mathrm{x}} \mathrm{W} / \mathrm{NF}$

\section{References}


Part 1 Experimental Supplement
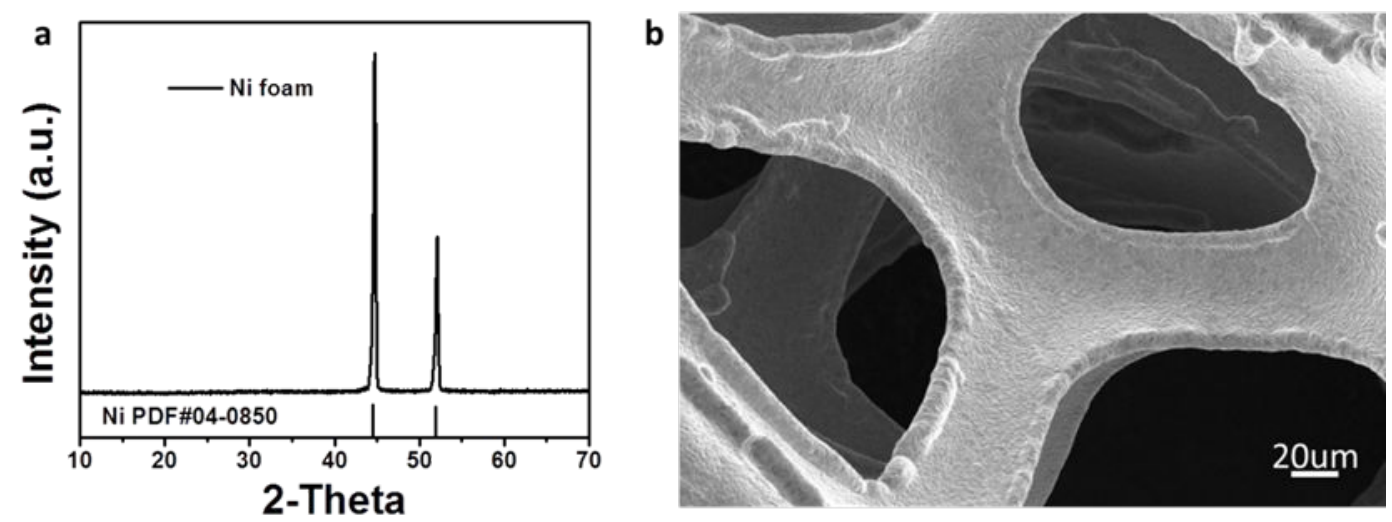

Figure S1. The XRD pattern (a) and SEM image (b) of nickel foam. 


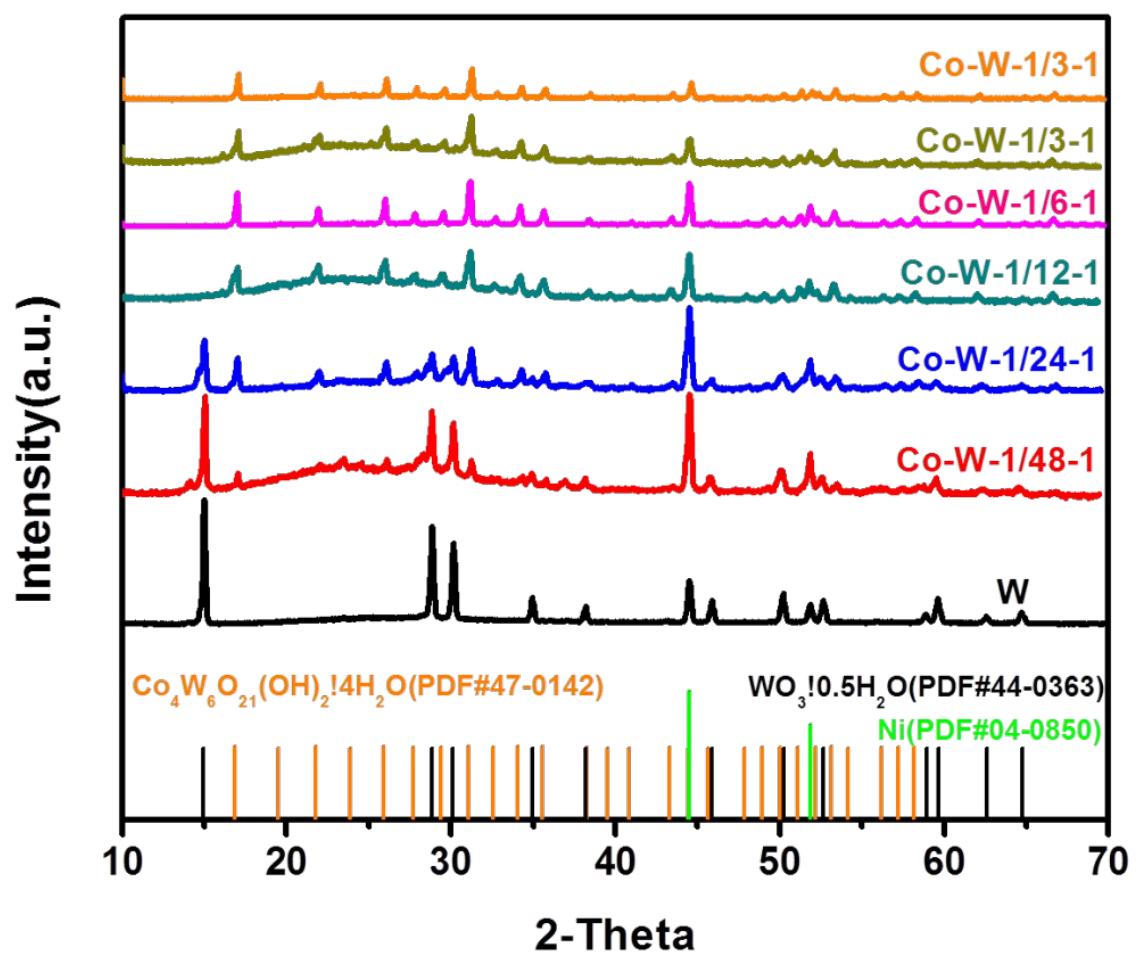

Figure S2. XRD patterns of precursors with different feeding ratios of Co and W. 


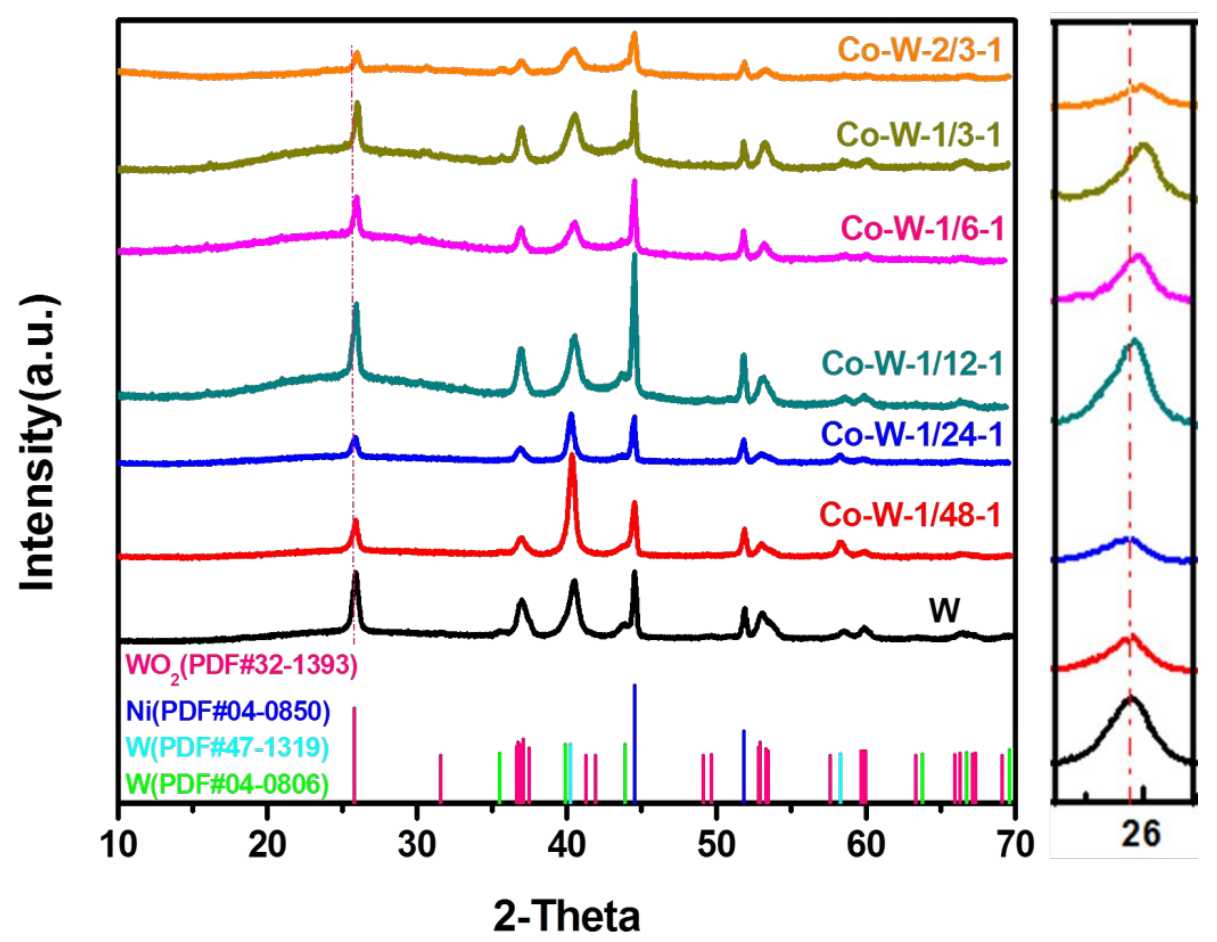

Figure S3. XRD patterns of $\mathrm{Co}-\mathrm{WO}_{2} / \mathrm{Co}_{\mathrm{x}} \mathrm{W} / \mathrm{NF}$ with different feeding ratios of Co and $\mathrm{W}$. 


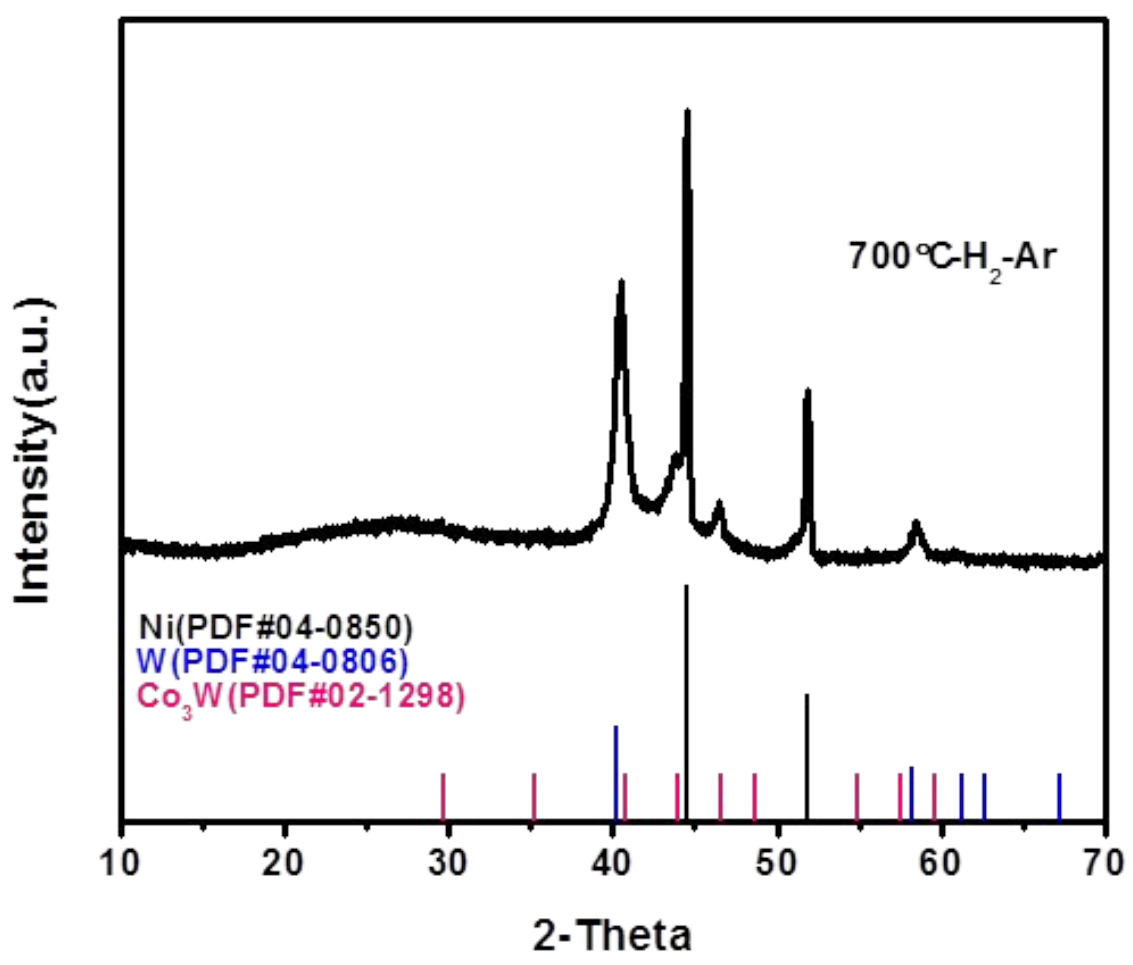

Figure S4. The XRD pattern of the catalyst annealed at $700{ }^{\circ} \mathrm{C}$ in $\mathrm{H}_{2}-\mathrm{Ar}$ gas mixture for 2 hours. 


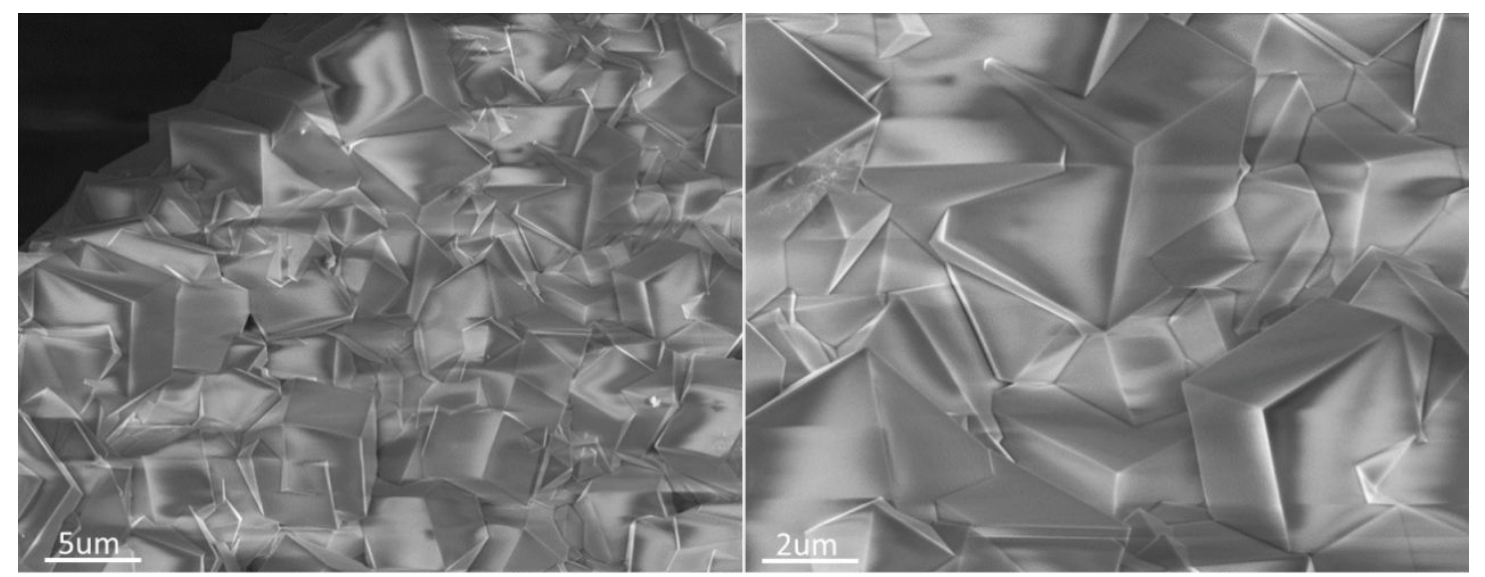

Figure S5. SEM images of precursor (Co-W-1/3-1). 


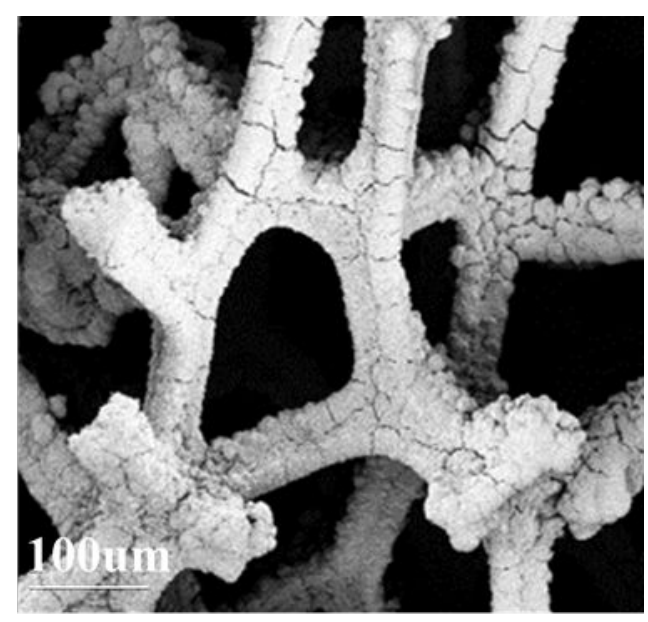

Figure S6. Low magnification SEM image of $\mathrm{Co}-\mathrm{WO}_{2} / \mathrm{Co}_{\mathrm{x}} \mathrm{W} / \mathrm{NF}-1 / 3$. 


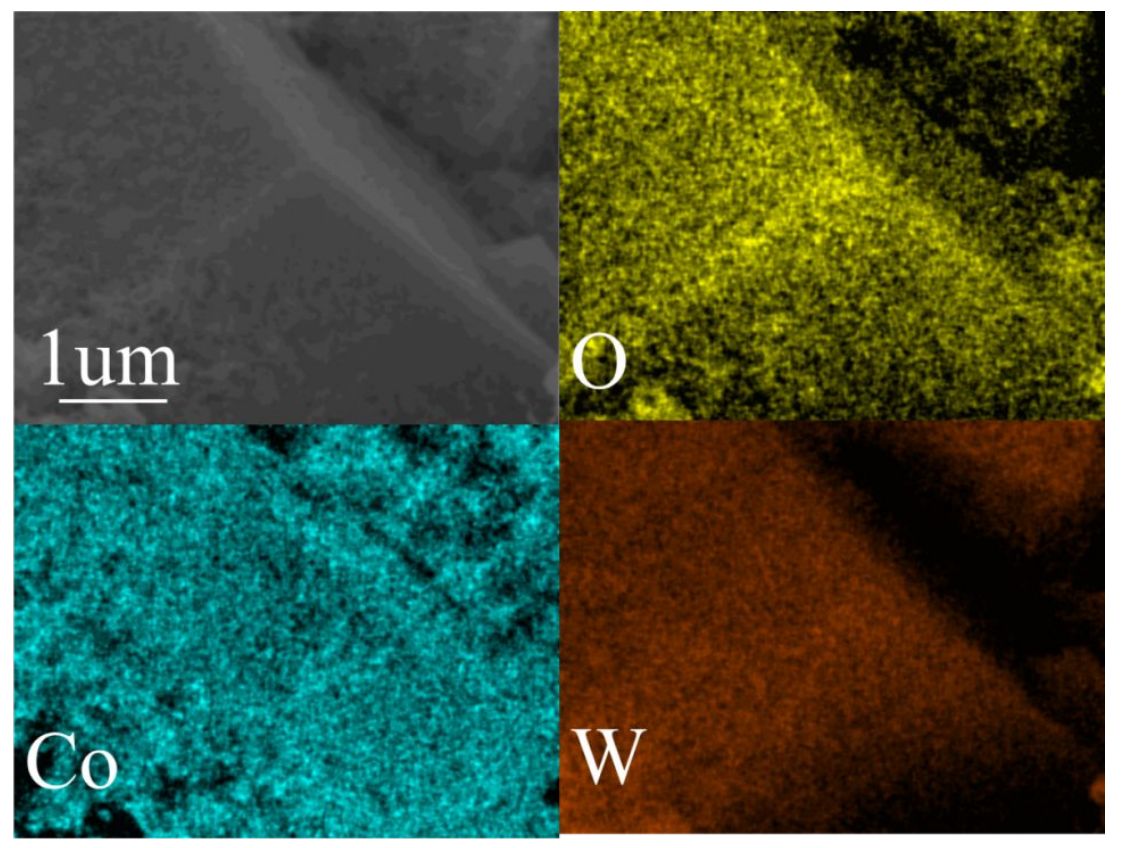

Figure S7. SEM image and corresponding Energy dispersive X-ray elemental mapping images of $\mathrm{Co}-\mathrm{WO}_{2} / \mathrm{Co}_{\mathrm{x}} \mathrm{W} / \mathrm{NF}-1 / 3$. 


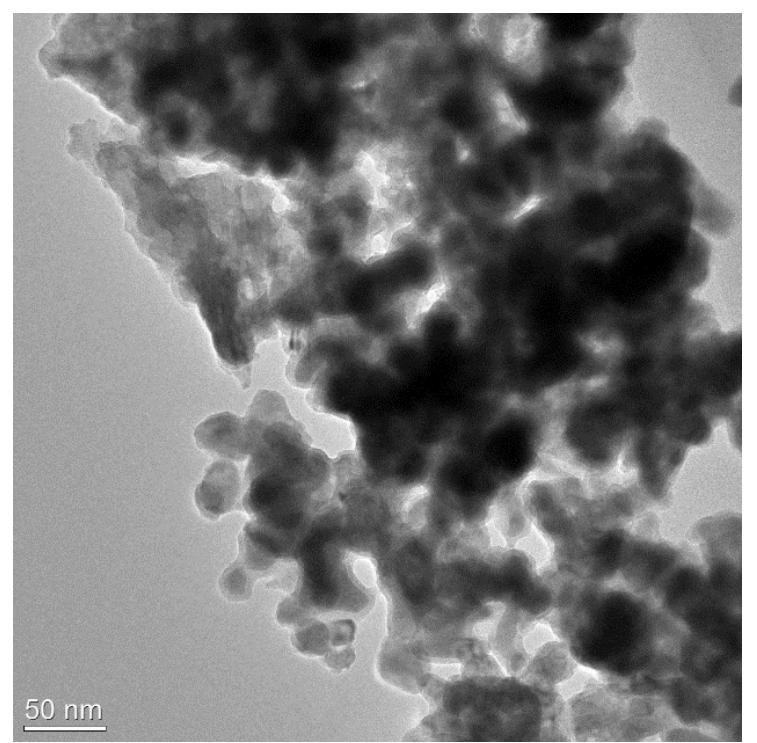

Figure S8. Low magnification TEM image of $\mathrm{Co}-\mathrm{WO}_{2} / \mathrm{Co}_{\mathrm{x}} \mathrm{W} / \mathrm{NF}-1 / 3$. 


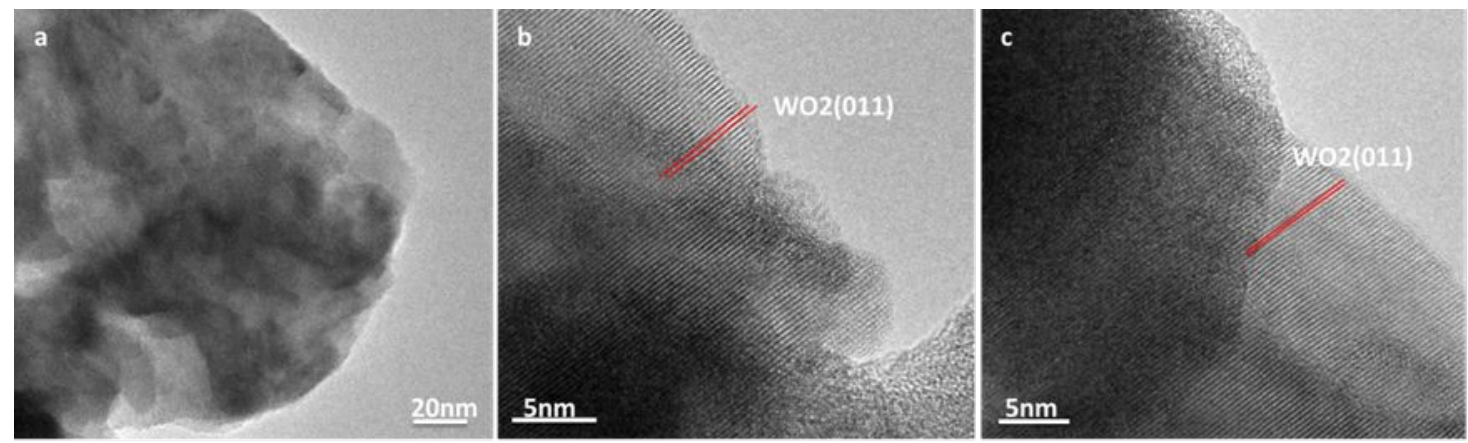

Figure S9. High magnification TEM images of Co- $\mathrm{WO}_{2} / \mathrm{Co}_{\mathrm{x}} \mathrm{W} / \mathrm{NF}-1 / 3$. 

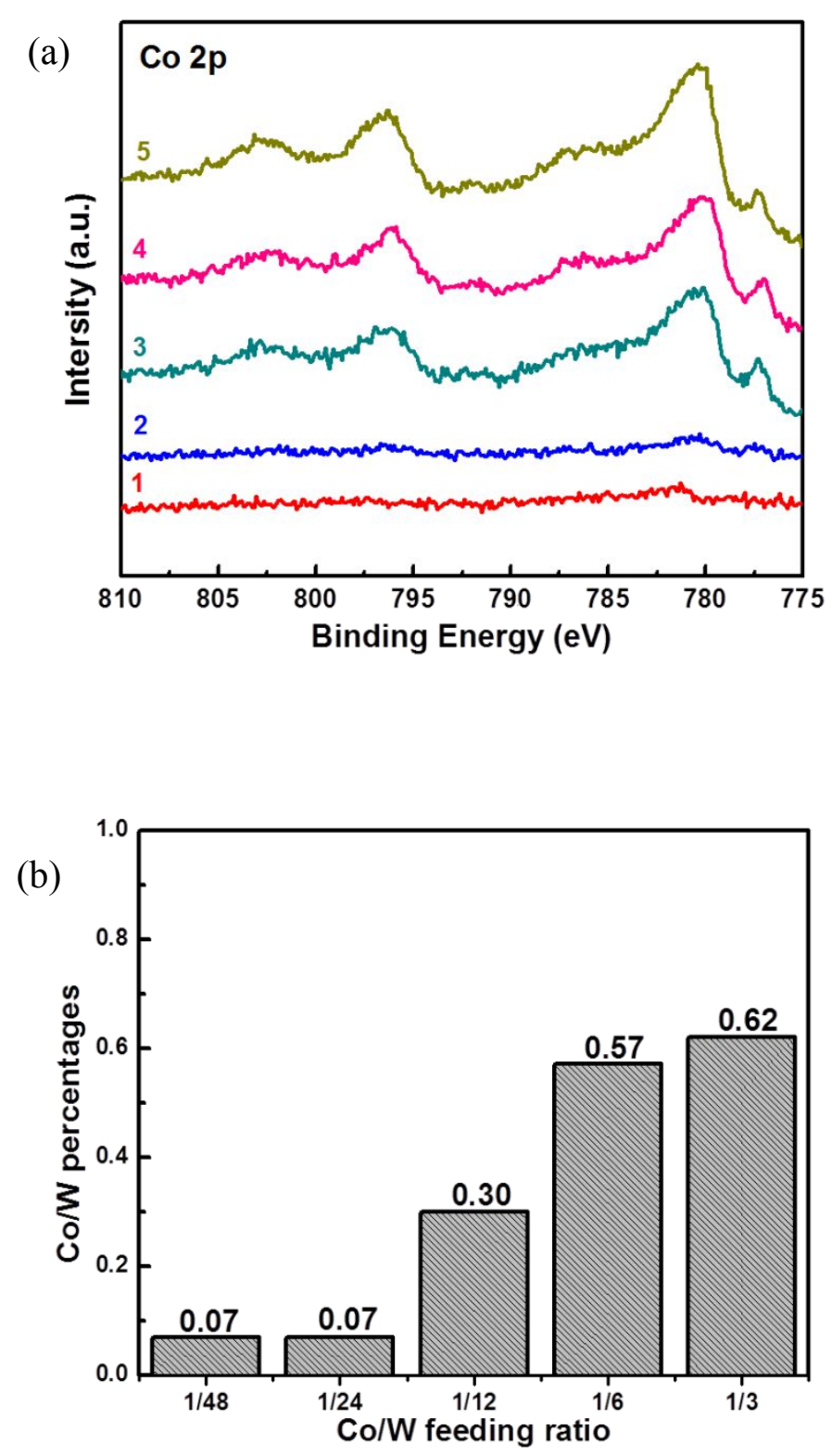

Figure S10. a) Co $2 p$ XPS spectra and b) $\mathrm{Co} / \mathrm{W}$ mole ratio of (1) $\mathrm{Co}-\mathrm{WO}_{2} / \mathrm{Co}_{\mathrm{x}} \mathrm{W} / \mathrm{NF}-1 / 48$, (2) Co- $\mathrm{WO}_{2} / \mathrm{Co}_{\mathrm{x}} \mathrm{W} / \mathrm{NF}-1 / 24$, (3) $\mathrm{Co}-\mathrm{WO}_{2} / \mathrm{Co}_{\mathrm{x}} \mathrm{W} / \mathrm{NF}-1 / 12$, (4) $\mathrm{Co}-\mathrm{WO}_{2} / \mathrm{Co}_{\mathrm{x}} \mathrm{W} / \mathrm{NF}-1 / 6$, and (5) $\mathrm{Co}-\mathrm{WO}_{2} / \mathrm{Co}_{\mathrm{x}} \mathrm{W} / \mathrm{NF}-1 / 3$. 

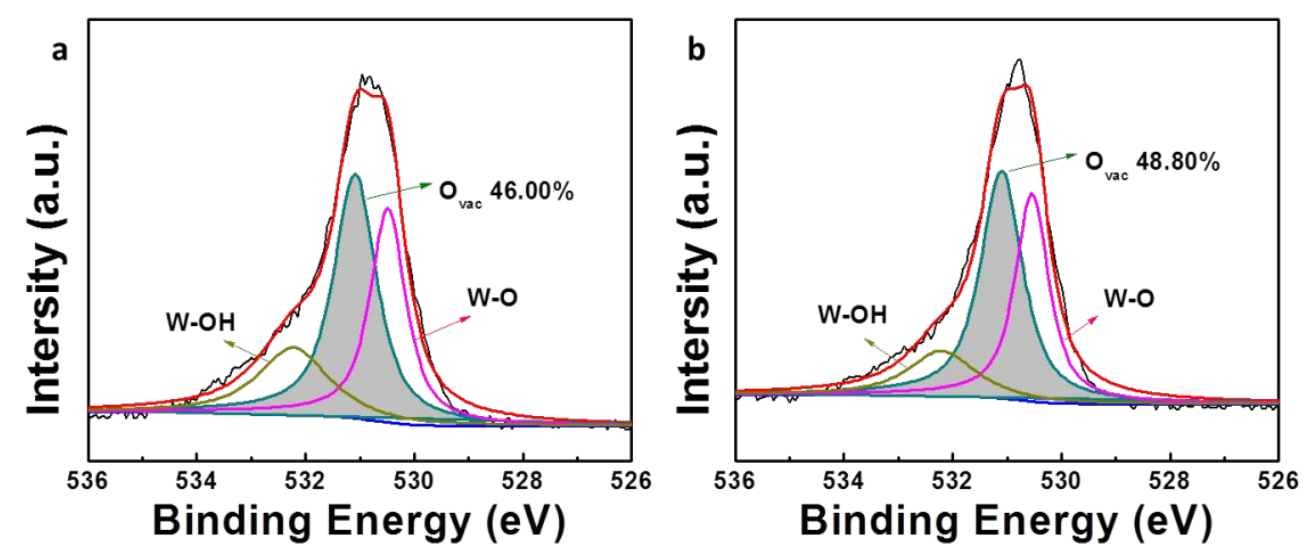

Figure S11. XPS spectrum of O $1 \mathrm{~s}$ of $\mathrm{WO}_{2} / \mathrm{NF}$ (a) and $\mathrm{Co}-\mathrm{WO}_{2} / \mathrm{Co}_{\mathrm{x}} \mathrm{W} / \mathrm{NF}-1 / 3$ (b). There are oxygen vacancies presenting both in $\mathrm{WO}_{2} / \mathrm{NF}$ and $\mathrm{Co}-\mathrm{WO}_{2} / \mathrm{Co}_{\mathrm{x}} \mathrm{W} / \mathrm{NF}-1 / 3$ and the oxygen vacancy ratio are $46.00 \%$ and $48.80 \%$, respectively. ${ }^{1-2}$ 

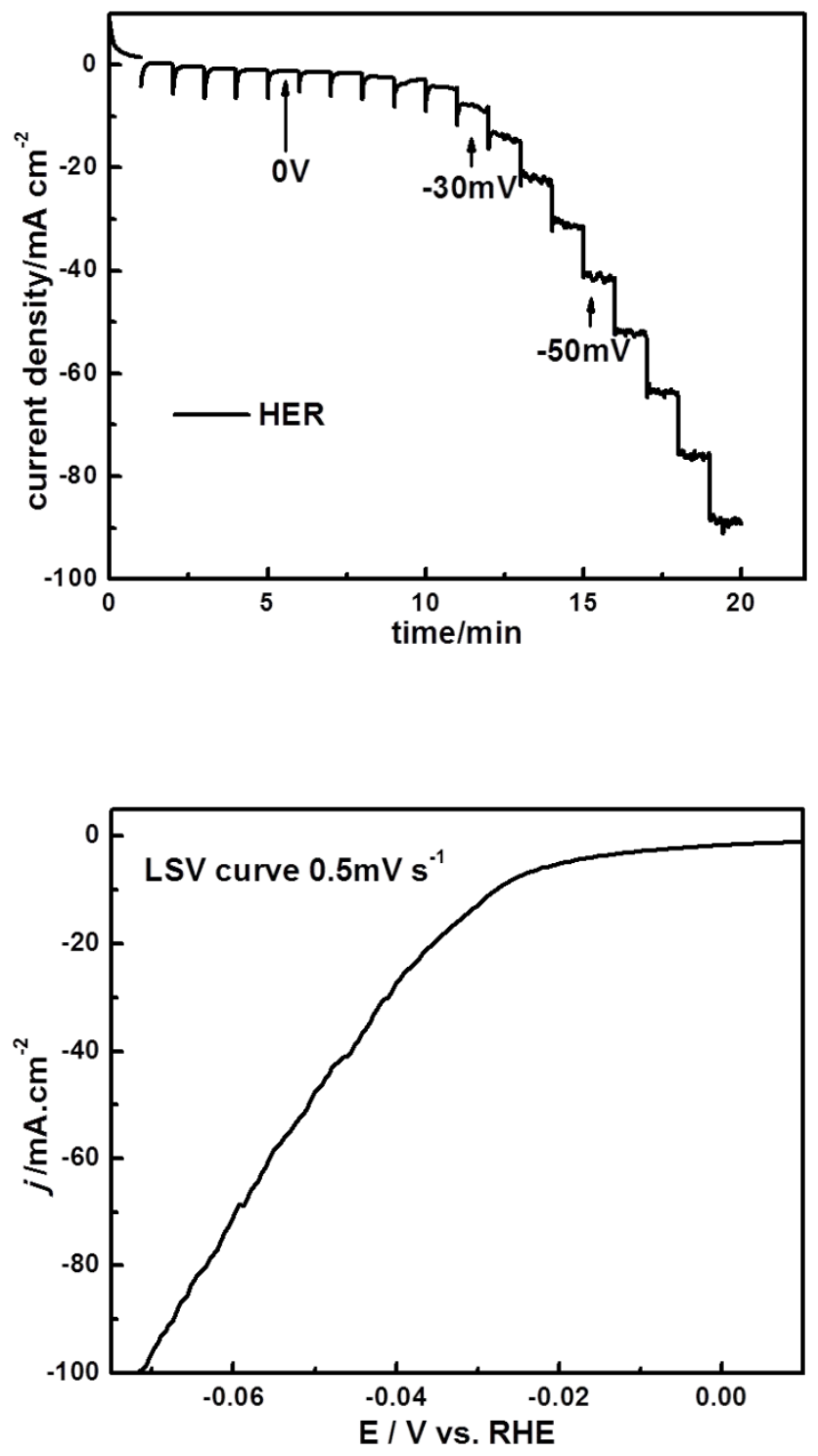

Figure S12. The polarization curve tested by step change method and the linear sweep voltammetry curve with a scan rate of $0.5 \mathrm{mV} \mathrm{s}{ }^{-1}$ of $\mathrm{Co}-\mathrm{WO}_{2} / \mathrm{Co}_{\mathrm{x}} \mathrm{W} / \mathrm{NF}-1 / 3$. 


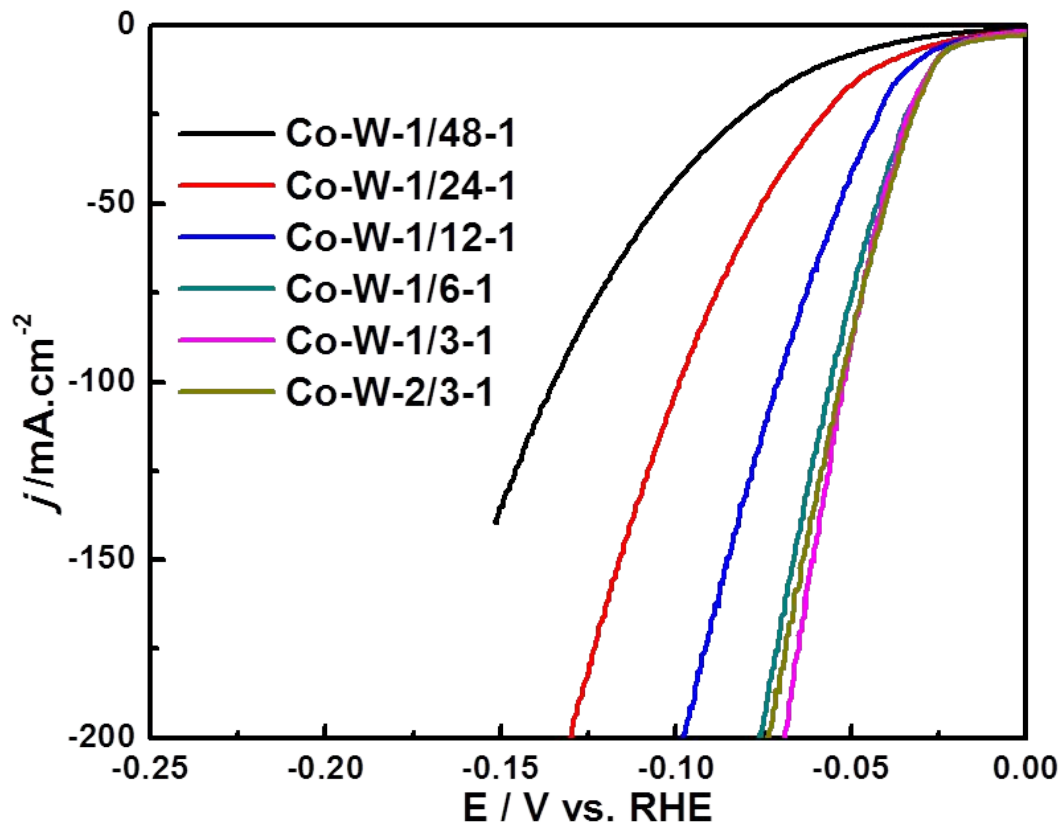

Figure S13. Polarization curves of $\mathrm{Co}-\mathrm{WO}_{2} / \mathrm{Co}_{\mathrm{x}} \mathrm{W} / \mathrm{NF}$ with different feeding ratio of Co and $\mathrm{W}$. 

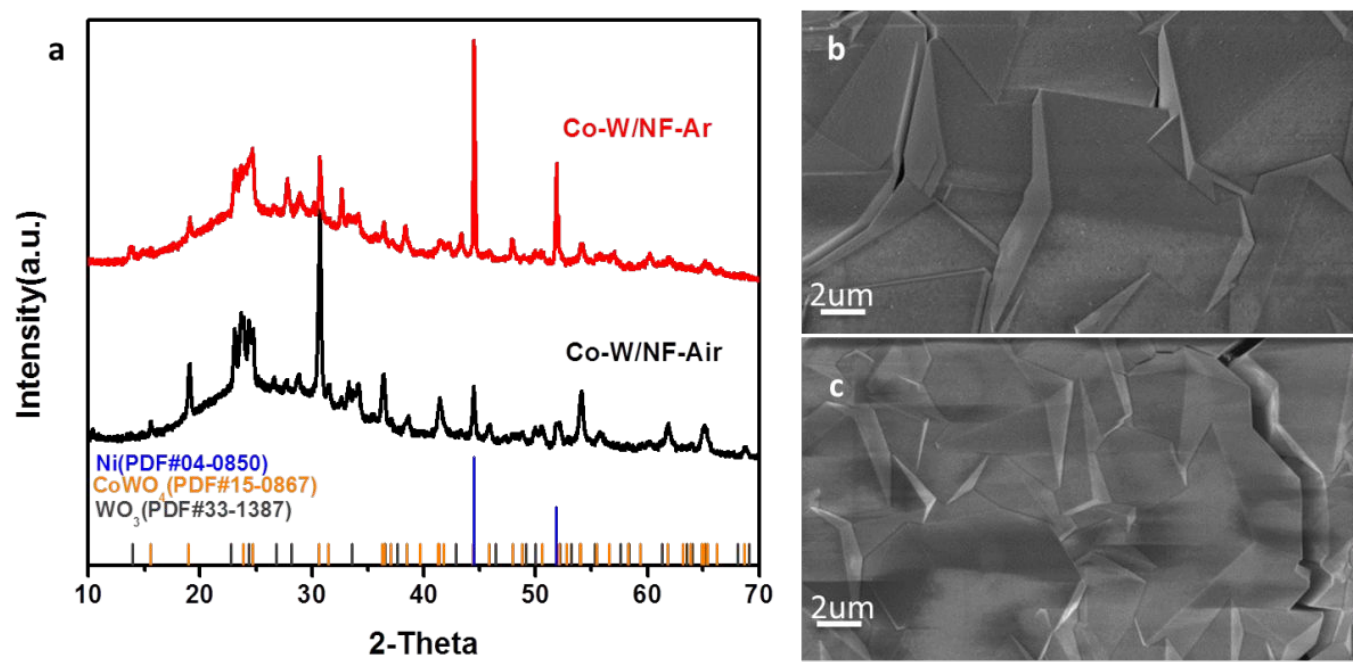

Figure S14. The XRD pattern of Co-W/NF-Air and Co-W/NF-Ar (a) and SEM image (b) and (c) of Co-W/NF-Air and Co-W/NF-Ar, respectively. 

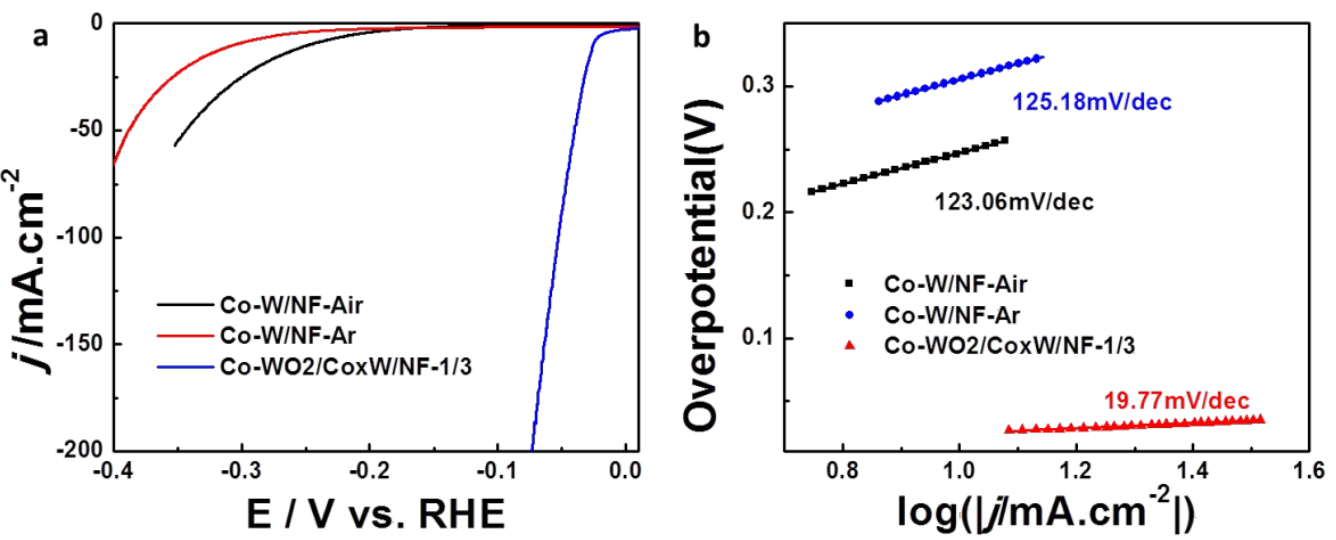

Figure S15. The Polarization curves (a) and Tafel slopes (b) of Co-W/NF-Air, $\mathrm{Co}-\mathrm{W} / \mathrm{NF}-\mathrm{Ar}$ and $\mathrm{Co}-\mathrm{WO} 2 / \mathrm{Co}_{\mathrm{x}} \mathrm{W} / \mathrm{NF}-1 / 3$, respectively. 


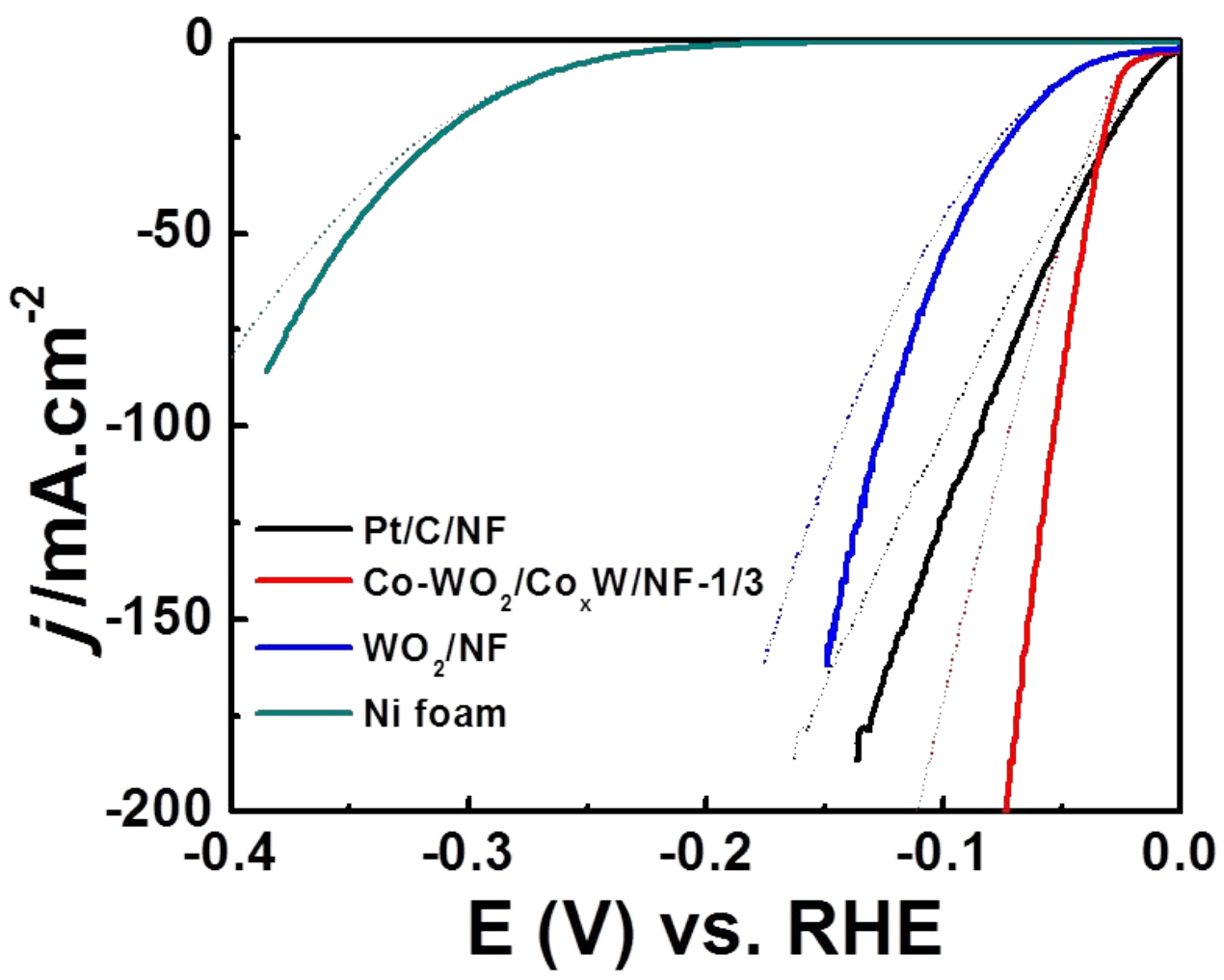

Figure 16. The LSV curves with (solid line) and without (short dot line) iR-compensated of the samples. 


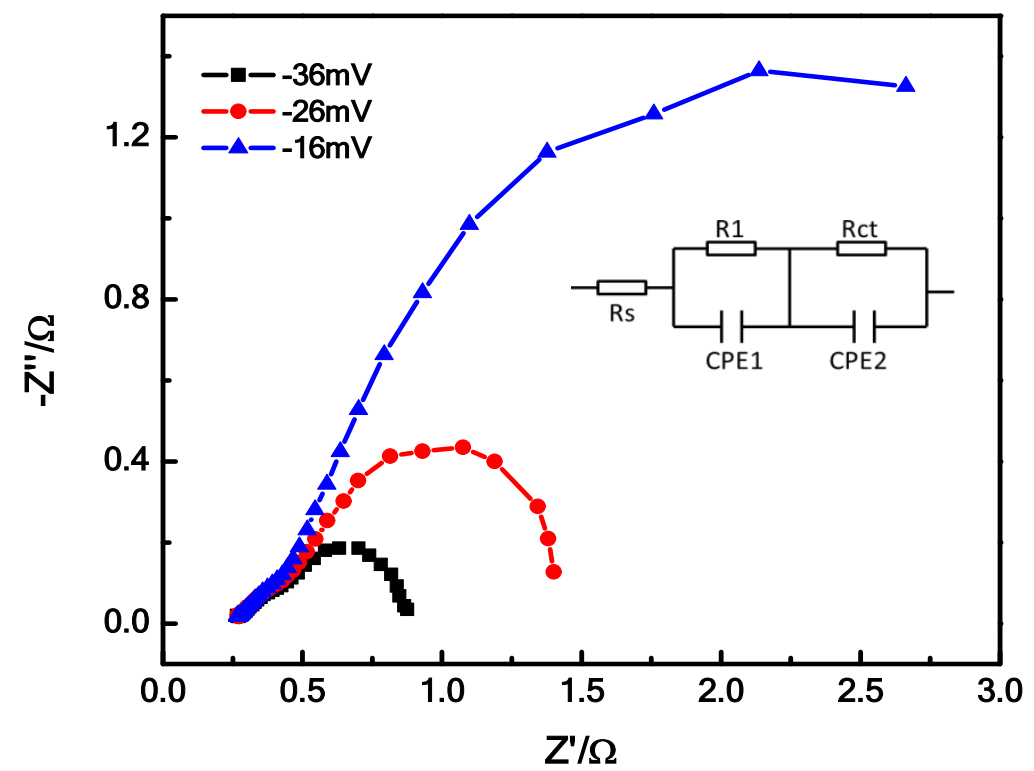

Figure S17. Nyquist plots of $\mathrm{Co}-\mathrm{WO}_{2} / \mathrm{Co}_{\mathrm{x}} \mathrm{W} / \mathrm{NF}-1 / 3$ at an overpotential of $16 \mathrm{mV}$, $26 \mathrm{mV}$ and $36 \mathrm{mV}$. Inset: the equivalent circuit diagram. 

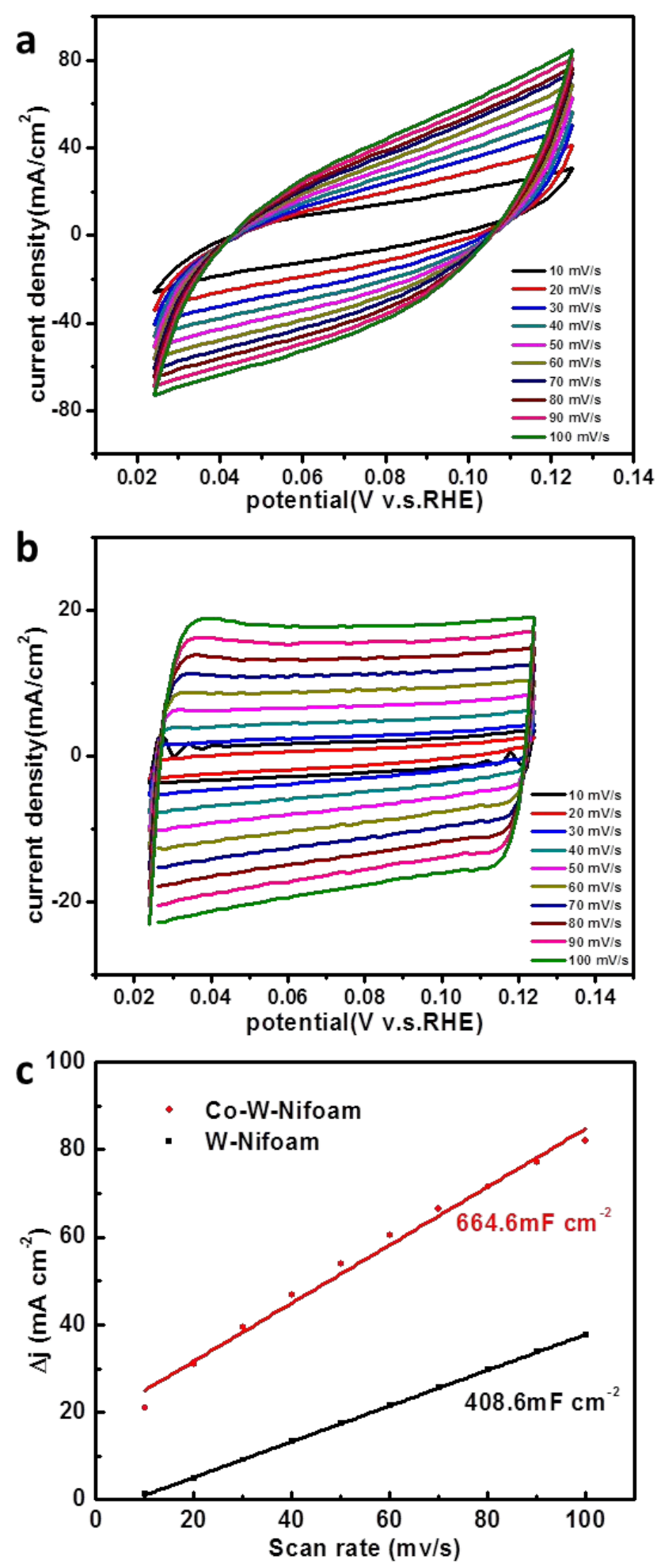

Figure S18. Cyclic voltammograms at different scan rates in the region between 0.024 and $0.124 \mathrm{~V}$ (vs. RHE) of a) $\mathrm{Co}-\mathrm{WO}_{2} / \mathrm{Co}_{\mathrm{x}} \mathrm{W} / \mathrm{NF}-1 / 3$ and b) $\mathrm{WO}_{2} / \mathrm{NF}$. c) Double-layer capacitance $\left(\mathrm{C}_{\mathrm{dl}}\right)$ of $\mathrm{Co}-\mathrm{WO}_{2} / \mathrm{Co}_{\mathrm{x}} \mathrm{W} / \mathrm{NF}-1 / 3$ and $\mathrm{WO}_{2} / \mathrm{NF}$. 


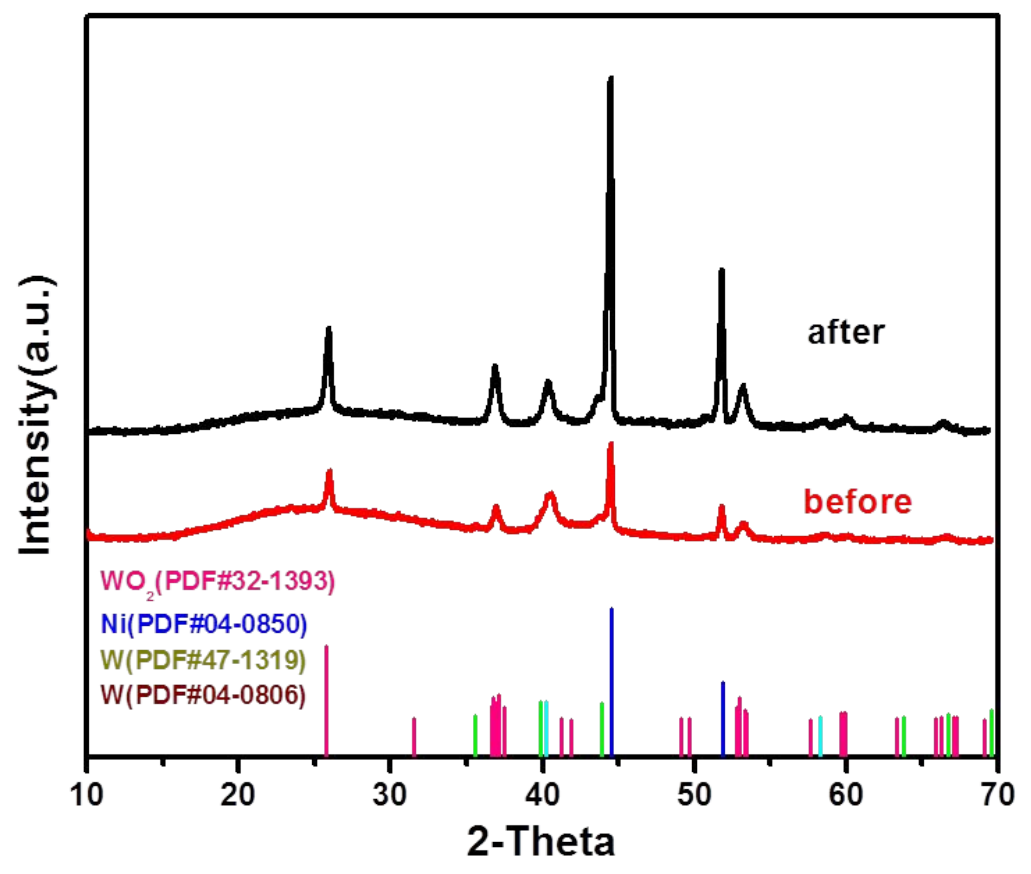

Figure S19. XRD patterns of $\mathrm{Co}-\mathrm{WO}_{2} / \mathrm{Co}_{\mathrm{x}} \mathrm{W} / \mathrm{NF}-1 / 3$ before and after chronoamperometry experiment. 


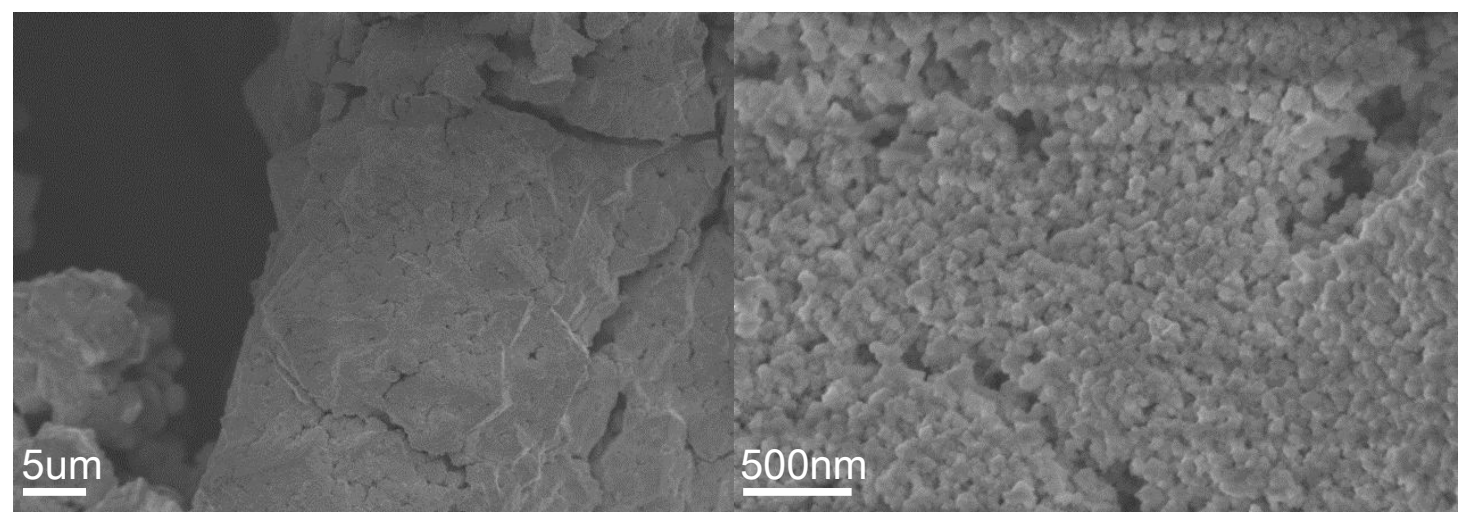

Figure S20. SEM images of $\mathrm{Co}-\mathrm{WO}_{2} / \mathrm{Co}_{\mathrm{x}} \mathrm{W} / \mathrm{NF}-1 / 3$ after chronoamperometry experiment. 


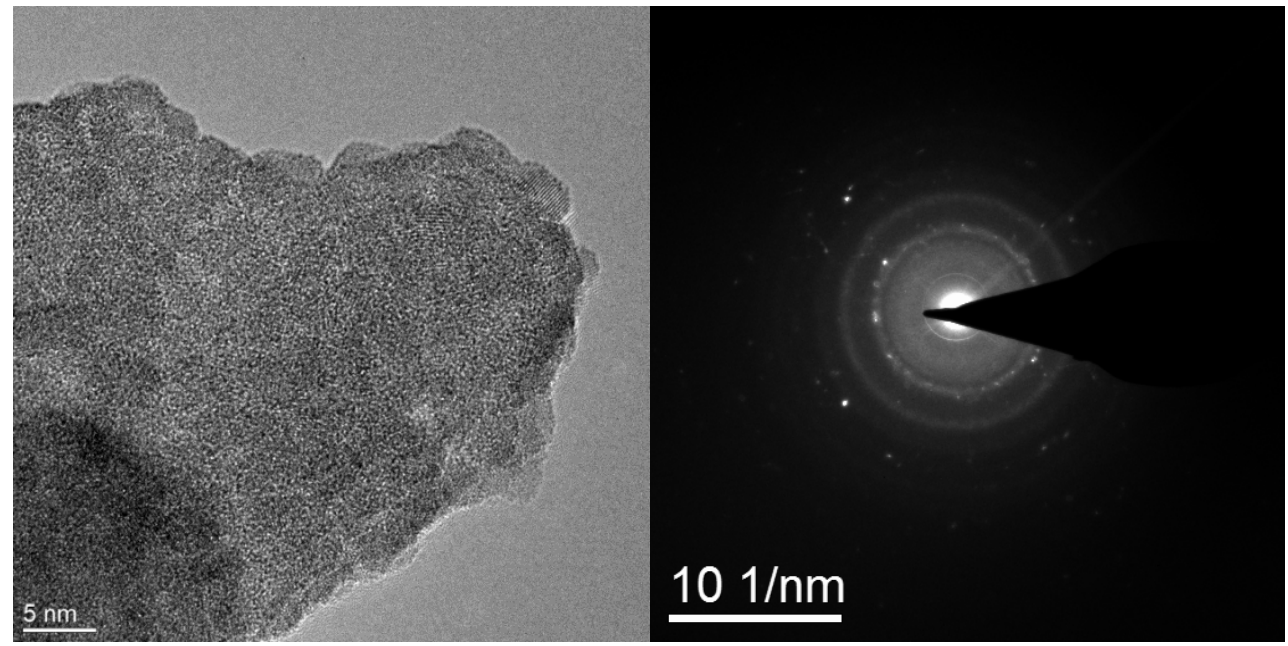

Figure S21. TEM image and SAED of the amorphous region of $\mathrm{Co}-\mathrm{WO}_{2} / \mathrm{Co}_{\mathrm{x}} \mathrm{W} / \mathrm{NF}-1 / 3$ after chronoamperometry experiment. 
Table S1. Comparisons of HER performance of $\mathrm{Co}-\mathrm{WO}_{2} / \mathrm{Co}_{\mathrm{x}} \mathrm{W} / \mathrm{NF}$ with other reported non-noble-metal catalysts.

\begin{tabular}{|c|c|c|c|c|}
\hline Electrocatalysts & Electrolyte & $\begin{array}{c}\text { Overpotential } \\
\text { at } 10 \mathrm{~mA} \mathrm{~cm}{ }^{-2}(\mathrm{mV})\end{array}$ & $\begin{array}{l}\text { Tafel solpe } \\
\left.(\mathrm{mV} \mathrm{dec})^{-1}\right)\end{array}$ & Ref. \\
\hline $\mathrm{Co}-\mathrm{WO}_{2} / \mathrm{Co}_{\mathrm{x}} \mathrm{W} / \mathrm{NF}$ & $1 \mathrm{M} \mathrm{KOH}$ & 25 & 19.77 & This work \\
\hline $\mathrm{Cu} @ \mathrm{NiFe} L D H$ & $1 \mathrm{M} \mathrm{KOH}$ & 116 & 58.9 & {$[1]^{3}$} \\
\hline $\mathrm{Ni}(\mathrm{OH})_{2} / \mathrm{MoS}_{2} @ \mathrm{CC}$ & $1 \mathrm{M} \mathrm{KOH}$ & 80 & 60 & {$[2]^{4}$} \\
\hline MoP@C & $1 \mathrm{M} \mathrm{KOH}$ & 49 & 54 & {$[3]^{5}$} \\
\hline $\begin{array}{c}\mathrm{Cu} \mathrm{NDs} / \mathrm{Ni}_{3} \mathrm{~S}_{2} \\
\mathrm{NTs}-\mathrm{CFs}\end{array}$ & $1 \mathrm{M} \mathrm{KOH}$ & 128 & 76.2 & {$[4]^{6}$} \\
\hline $\mathrm{WO}_{2} \mathrm{HN} / \mathrm{NF}$ & $1 \mathrm{M} \mathrm{KOH}$ & 48 & 43 & {$[5]^{7}$} \\
\hline NiFeIr LDH & $1 \mathrm{M} \mathrm{KOH}$ & 34 & 32 & {$[6]^{8}$} \\
\hline $\mathrm{WO}_{3} / \mathrm{C} @ \mathrm{CoO} / \mathrm{NF}$ & $1 \mathrm{M} \mathrm{KOH}$ & 55 & 115 & {$[7]^{9}$} \\
\hline $\mathrm{O}, \mathrm{Cu}-\mathrm{CoP}$ & $1 \mathrm{M} \mathrm{KOH}$ & 72 & 62.2 & {$[8]^{10}$} \\
\hline $\mathrm{Ni}_{5} \mathrm{P}_{4} @ \mathrm{NiCo}_{2} \mathrm{O}_{4}$ & $1 \mathrm{M} \mathrm{KOH}$ & 27 & 27 & {$[9]^{11}$} \\
\hline $\mathrm{Co}-\mathrm{Mo}_{2} \mathrm{C}$ & $1 \mathrm{M} \mathrm{KOH}$ & 118 & 44 & {$[10]^{12}$} \\
\hline $\mathrm{Co}_{2} \mathrm{Mo}_{3} \mathrm{O}_{8} / \mathrm{Co} / \mathrm{NF}$ & $1 \mathrm{M} \mathrm{KOH}$ & 50 & 49 & {$[11]^{13}$} \\
\hline $\begin{array}{c}\text { Ni2P-Ni3S2 } \\
\text { HNAs/NF }\end{array}$ & $1 \mathrm{M} \mathrm{KOH}$ & 80 & 65 & {$[12]^{14}$} \\
\hline WN NW/CC & $1 \mathrm{M} \mathrm{KOH}$ & 130 & 57.1 & {$[13]^{15}$} \\
\hline $\mathrm{p}-\mathrm{WCx}$ NWs/CC & $1 \mathrm{M} \mathrm{KOH}$ & 122 & 56 & {$[14]^{16}$} \\
\hline $\mathrm{MoNi}_{4}$ & $1 \mathrm{M} \mathrm{KOH}$ & 15 & 30 & {$[15]^{17}$} \\
\hline
\end{tabular}




\section{Part 2 Calculational Supplement}

At ambient conditions, $\mathrm{WO}_{2}$ crystallizes in monoclinic structure with space group $\mathrm{P} 21 / \mathrm{c}$ and 4 formula in the unit cell. Our simulated structural parameters are $\mathrm{a}=5.586$ $\AA, b=4.940 \AA, c=5.712 \AA$ and $\beta=120.37^{\circ}$, which are in good agreement with the experimental results $^{18}$ of $\mathrm{a}=5.563 \AA, \mathrm{b}=4.896 \AA, \mathrm{c}=5.663 \AA$ and $\beta=120.47^{\circ}$, indicating that our simulation parameters are accurate to describe the structures.

Amorphous phase of $\mathrm{Co}_{\mathrm{x}} \mathrm{W}$ alloy were generated using ab initio molecular dynamics implemented in VASP. We started from a slab containing randomly arranged $37 \mathrm{Co}$ atoms and $29 \mathrm{~W}$ atoms and then the model was heated to $4000 \mathrm{~K}$ and allowed to equilibrate at this temperature for $700 \mathrm{MD}$ steps (each MD step $=3 \mathrm{fs}$ ). To obtain the amorphous phase, the model was cooled to $1000 \mathrm{~K}$ temperature at a rapid rate of $500 \mathrm{~K}$ per $200 \mathrm{MD}$ steps and then to room temperature of $100 \mathrm{~K}$ per $114 \mathrm{MD}$ steps. We selected a structure corresponding to one of the configurations obtained at room temperature with lowest free energy and relaxed it till the forces tolerance of 0.02 $\mathrm{eV} / \AA$.

As shown in Figure S22, $\mathrm{WO}_{2}(011)$ and $\mathrm{Co}-\mathrm{WO}_{2}(011)$ have four adsorption sites and the corresponding adsorption free energies of adsorbates of $\left(\mathrm{H}_{2} \mathrm{O}\right.$ and $\left.\mathrm{H}\right)$ on them are probed in order to determine the reaction path as shown in Table S3. As for the amorphous $\mathrm{Co}_{\mathrm{x}} \mathrm{W}$, ten different adsorption sites were probed for both $\mathrm{H}_{2} \mathrm{O}$ and $\mathrm{H}$ due to the less symmetry and only the most energetically favored case was listed in the Table. The adsorption free energy for adsorbates was calculated according to the equation (1): 
where $\Delta \mathrm{E}$ is the chemisorption energy, $\Delta \mathrm{E}_{\mathrm{ZPE}}$ is the correction of zero-point energy, $\Delta \mathrm{S}_{\mathrm{H}}$ is the entropy difference between the adsorbed state and gas state and $\mathrm{T}$ is the room temperature (300K). $\Delta \mathrm{E}$ was calculated according to the equation (2):

$\Delta \mathrm{E}=\mathrm{E}_{\text {sub-ads }}-\mathrm{E}_{\mathrm{sub}}-\mathrm{E}_{\mathrm{ads}}$

where $\mathrm{E}_{\text {sub-ads }}$ is the total energy of substrate and adsorbate, $\mathrm{E}_{\text {sub }}$ is the energy of the substrate and $E_{a d s}$ is the energy of adsorbate. Our calculations show that the corrections of zero-point energy and entropy difference are almost site independent and are $0.67 \mathrm{eV}$ and $0.22 \mathrm{eV}$ for the adsorption of $\mathrm{H}_{2} \mathrm{O}$ and $\mathrm{H}$, respectively.

To further investigate the reaction pathway, the free energy barriers of the whole HER process on $\mathrm{Co}-\mathrm{WO}_{2}$ were calculated using climbing image nudged elastic band method as listed in Table S4. ${ }^{19}$ 


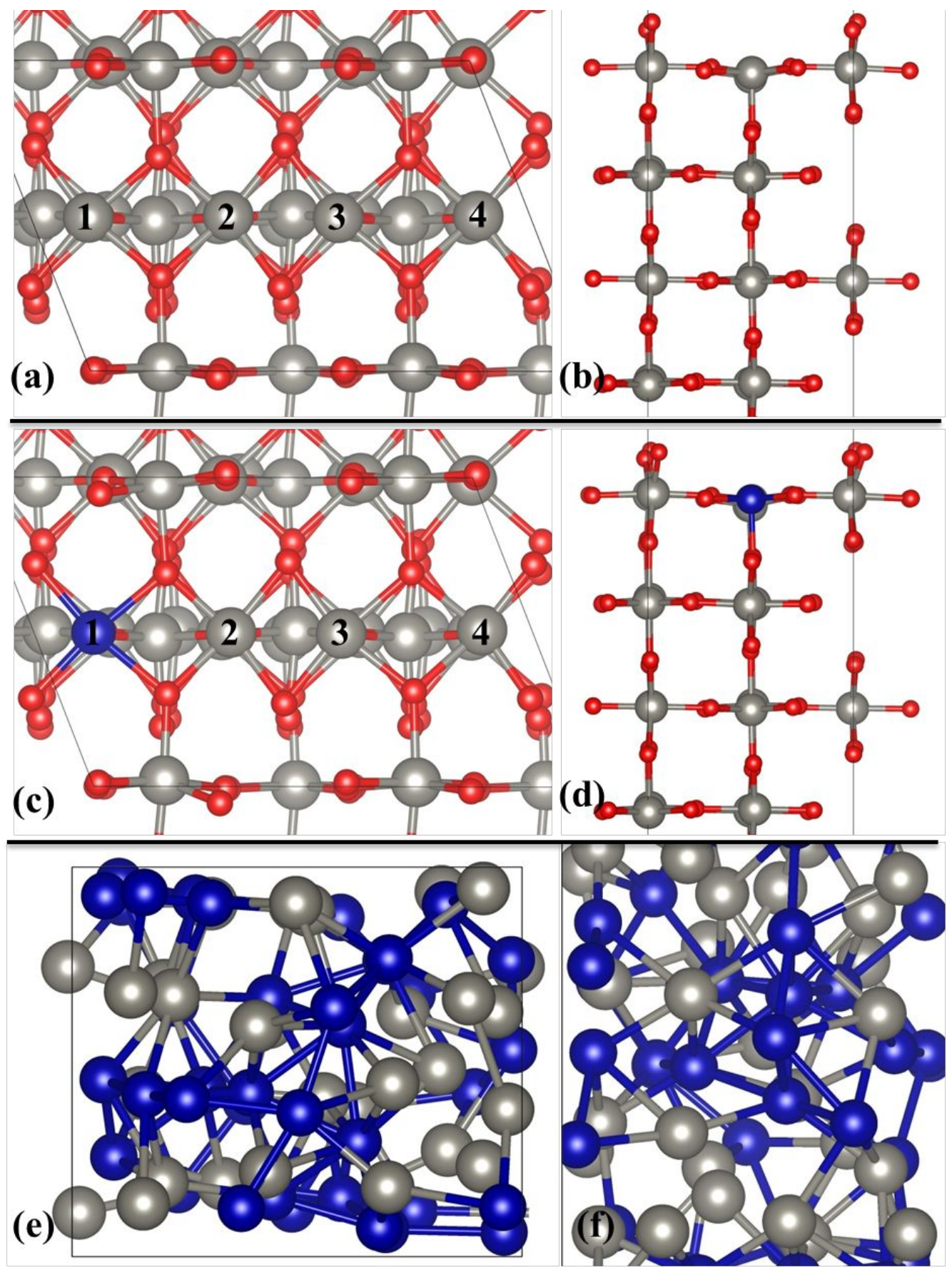

Figure S22. The top views (a, c and e) and side views (b, d and f) of the as-built models of $\mathrm{WO}_{2}(011), \mathrm{Co}-\mathrm{WO}_{2}(011)$ and amorphous $\mathrm{Co}_{\mathrm{x}} \mathrm{W}$ slab, respectively. 
Table S2. Surface energies $\left(\mathrm{J} / \mathrm{m}^{2}\right)$ of different surfaces of $\mathrm{WO}_{2}$

\begin{tabular}{llllllll}
\hline & $(001)$ & $(010)$ & $(100)$ & $(011)$ & $(110)$ & $(200)$ & $(201)$ \\
\hline $\mathrm{E}_{\text {surf }}$ & 3.99 & 3.53 & 3.19 & 2.22 & 3.34 & 3.13 & 3.91 \\
\hline
\end{tabular}

The surface energy is calculated based on the following equation:

$\mathrm{E}_{\text {surf }}=\left(\mathrm{E}_{\mathrm{slab}}-n \mathrm{E}_{\mathrm{bulk}}\right) / A$

where $\mathrm{E}_{\text {surf }}$ is the surface energy, $\mathrm{E}_{\text {slab }}$ the energy of the slab model of $\mathrm{WO}_{2}$ surface,

$\mathrm{E}_{\text {bulk }}$ the energy of unit cell of bulk phase of $\mathrm{WO}_{2}, n$ the number of unit cell and $A$ the surface area of the slab model.

Table S3. The adsorption free energies $(\mathrm{eV})$ of $\mathrm{H}_{2} \mathrm{O}$ and $\mathrm{H}$ on $\mathrm{WO}_{2}(011), \mathrm{Co}-\mathrm{WO}_{2}$ (011) and $\mathrm{Co}_{\mathrm{x}} \mathrm{W}$, respectively.

\begin{tabular}{|c|c|c|c|c|c|c|c|c|}
\hline & \multicolumn{2}{|c|}{ Site 1} & \multicolumn{2}{|c|}{ Site 2} & \multicolumn{2}{|c|}{ Site 3} & \multicolumn{2}{|c|}{ Site 4} \\
\hline & $\mathrm{H}_{2} \mathrm{O}$ & $\mathrm{H}$ & $\mathrm{H}_{2} \mathrm{O}$ & $\mathrm{H}$ & $\mathrm{H}_{2} \mathrm{O}$ & $\mathrm{H}$ & $\mathrm{H}_{2} \mathrm{O}$ & $\mathrm{H}$ \\
\hline $\mathrm{WO}_{2}(011)$ & -0.66 & -0.40 & -0.33 & -0.30 & -0.66 & -0.40 & -0.33 & -0.30 \\
\hline $\mathrm{Co}-\mathrm{WO}_{2}(011)$ & 0.12 & 0.68 & -0.27 & -0.06 & -0.61 & -0.28 & -0.25 & -0.10 \\
\hline $\mathrm{Co}_{\mathrm{x}} \mathrm{W}$ & -0.88 & -1.88 & - & - & - & - & - & - \\
\hline
\end{tabular}

Table S4. Free energy barriers (eV) of Volmer, Tafel, and Heyrovsky steps.

\begin{tabular}{cccc}
\hline & Volmer & Tafel & Heyrovsky \\
\hline Co- $\mathrm{WO}_{2}(011)$ & 1.25 & 0.29 & 0.38 \\
\hline
\end{tabular}




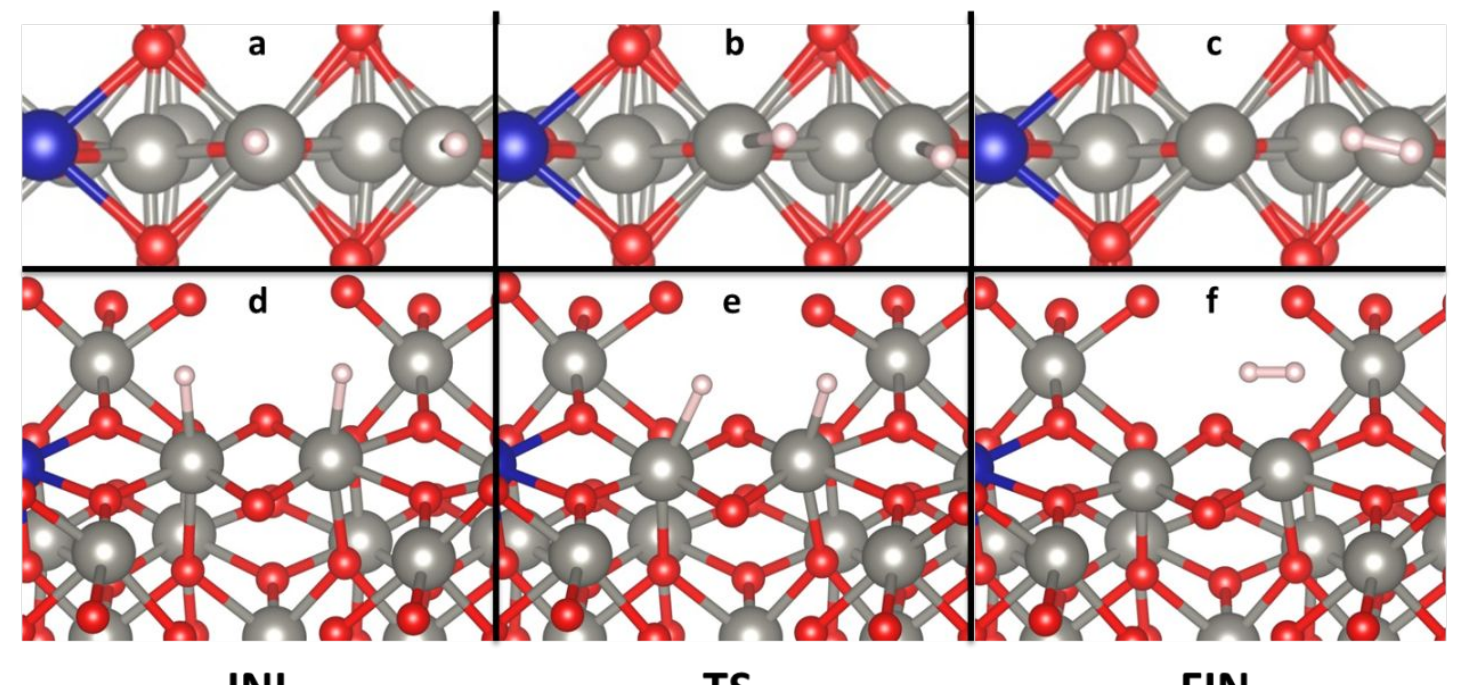

INI

TS

FIN

Figure S23. The top view (a-c) and the side view (d-f) of the Tafel step on $\mathrm{Co}-\mathrm{WO}_{2} / \mathrm{Co}_{\mathrm{x}} \mathrm{W} / \mathrm{NF}$, including atomic configurations of reactant initial states, transition states, final states. 


\section{References}

(1) Zhu, C.; Fu, S.; Du, D.; Lin, Y., Facilely Tuning Porous $\mathrm{NiCo}_{2} \mathrm{O}_{4}$ Nanosheets with Metal Valence-State Alteration and Abundant Oxygen Vacancies as Robust Electrocatalysts Towards Water Splitting. Chem. Eur. J. 2016, 22, 4000-4007.

(2) Zhuang, L.; Ge, L.; Yang, Y.; Li, M.; Jia, Y.; Yao, X.; Zhu, Z., Ultrathin Iron-Cobalt Oxide Nanosheets with Abundant Oxygen Vacancies for the Oxygen Evolution Reaction. Adv. Mater. 2017, 29, 1606793.

(3) Yu, L.; Zhou, H.; Sun, J.; Qin, F.; Yu, F.; Bao, J.; Yu, Y.; Chen, S.; Ren, Z. Cu Nanowires Shelled with NiFe Layered Double Hydroxide Nanosheets as Bifunctional Electrocatalysts for Overall Water Splitting. Energy Environ. Sci. 2017, 10, 1820-1827.

(4) Zhang, B.; Liu, J.; Wang, J.; Ruan, Y.; Ji, X.; Xu, K.; Chen, C.; Wan, H.; Miao, L.; Jiang, J. Interface Engineering: The $\mathrm{Ni}(\mathrm{OH})_{2} / \mathrm{MoS}_{2}$ Heterostructure for Highly Efficient Alkaline Hydrogen Evolution. Nano Energy 2017, 37, 74-80.

(5) Li, G.; Sun, Y.; Rao, J.; Wu, J.; Kumar, A.; Xu, Q. N.; Fu, C.; Liu, E.; Blake, G. R.; Werner, P.; Shao, B.; Liu, K.; Parkin, S.; Liu, X.; Fahlman, M.; Liou, S. C.; Auffermann, G.; Zhang, J.; Felser, C.; Feng, X. Carbon-Tailored Semimetal MoP as an Efficient Hydrogen Evolution Electrocatalyst in Both Alkaline and Acid Media. Adv. Energy Mater. 2018, 8, 1801258.

(6) Feng, J. X.; Wu, J. Q.; Tong, Y. X.; Li, G. R. Efficient Hydrogen Evolution on $\mathrm{Cu}$ Nanodots-Decorated $\mathrm{Ni}_{3} \mathrm{~S}_{2}$ Nanotubes by Optimizing Atomic Hydrogen Adsorption and Desorption. J. Am. Chem. Soc. 2018, 140, 610-617.

(7) Shu, C.; Kang, S.; Jin, Y.; Yue, X.; Shen, P. K. Bifunctional Porous Non-precious Metal $\mathrm{WO}_{2}$ Hexahedral Networks as an Electrocatalyst for Full Water Splitting. $J$. Mater. Chem. A 2017, 5, 9655-9660.

(8) Chen Q.; Hou C.; Wang C.; Yang X.; Shi R.; Chen Y. Ir(4+)-Doped NiFe LDH to Expedite Hydrogen Evolution Kinetics as a Pt-like Electrocatalyst for Water Splitting. Chem. Commun. (Camb) 2018, 54, 6400-6403.

(9) Lv Y.; Liu Y.; Chen C.; Wang T.; Zhang M. Octopus Tentacles-like $\mathrm{WO}_{3} / \mathrm{C} @ \mathrm{CoO}$ as High Property and Long Life-time Electrocatalyst for Hydrogen Evolution Reaction. Electrochim. Acta 2018, 281, 1-8.

(10)Xu, K.; Sun, Y.; Sun, Y.; Zhang, Y.; Jia, G.; Zhang, Q.; Gu, L.; Li, S.; Li, Y.; Fan, H. J. Yin-Yang Harmony: Metal and Nonmetal Dual-Doping Boosts Electrocatalytic Activity for Alkaline Hydrogen Evolution. ACS Energy Lett. 2018, 3, 2750-2756. 
(11)Zhang, T.; Yang, K.; Wang, C.; Li, S.; Zhang, Q.; Chang, X.; Li, J.; Li, S.; Jia, S.; Wang, J.; Fu, L. Nanometric $\mathrm{Ni}_{5} \mathrm{P}_{4}$ Clusters Nested on $\mathrm{NiCo}_{2} \mathrm{O}_{4}$ for Efficient Hydrogen Production via Alkaline Water Electrolysis. Adv. Energy Mater. 2018, 8, 1801690.

(12) Lin, H.; Liu, N.; Shi, Z.; Guo, Y.; Tang, Y.; Gao, Q. Cobalt-doping in Molybdenum-Carbide Nanowires Toward Efficient Electrocatalytic Hydrogen Evolution. Adv. Funct. Mater. 2016, 26, 5590-5598.

(13) Ou, Y.; Tian, W.; Liu, L.; Zhang, Y.; Xiao, P. Bimetallic $\mathrm{Co}_{2} \mathrm{Mo}_{3} \mathrm{O}_{8}$ Suboxides Coupled with Conductive Cobalt Nanowires for Efficient and Durable Hydrogen Evolution in Alkaline Electrolyte. J. Mater. Chem. A 2018, 6, 5217-5228.

(14) Zeng, L.; Sun, K.; Wang, X.; Liu, Y.; Pan, Y; Liu, Z.; Cao, D.; Song, Y.; Liu, S.; Liu, C. Three-dimensional-networked $\mathrm{Ni}_{2} \mathrm{P} / \mathrm{Ni}_{3} \mathrm{~S}_{2}$ Heteronanoflake Arrays for Highly Enhanced Electrochemical Overall-water-splitting Activity. Nano Energy 2018, 51, 26-36.

(15) Ren, B.; Li, D.; Jin, Q.; Cui, H.; Wang, C. A Self-supported Porous WN Nanowire Array: an Efficient 3D Electrocatalyst for the Hydrogen Evolution Reaction. J. Mater. Chem. A 2017, 5, 19072-19078.

(16) Ren, B.; Li, D.; Jin, Q.; Cui, H.; Wang, C. Novel Porous Tungsten Carbide Hybrid Nanowires on Carbon Cloth for High-performance Hydrogen Evolution. $J$. Mater. Chem. A 2017, 5, 13196-13203.

(17) Zhang, J.; Wang, T.; Liu, P.; Liao, Z.; Liu, S.; Zhuang, X.; Chen, M.; Zschech, E.; Feng, X. Efficient Hydrogen Production on $\mathrm{MoNi}_{4}$ Electrocatalysts with Fast Water Dissociation Kinetics. Nat Commun. 2017, 8, 15437.

(18) Palmer D.J.; Dickens P.G. Tungsten Dioxide: Structure Refinement by Powder Neutron Diffraction. Acta Crystallogr., Section B 1979, 35, 2199-2201.

(19) Henkelman G.; Uberuaga B.P.; Jónsson H. A Climbing Image Nudged Elastic Band Method for Finding Saddle Points and Minimum Energy Paths. J. Chem. Phys. 2000, 113, 9901- 9904 . 